\title{
How Cultural Parenting Impacts Children's Academics and Creativity
}

\author{
Kyung Hee Kim \\ William \& Mary, Williamsburg, USA \\ E-mail address: kkim@wm.edu
}

\author{
Yi Hua \\ William \& Mary, Williamsburg, USA \\ E-mail address: yhua@email.wm.edu
}

\section{ARTICLE INFO}

\section{Keywords:}

Creativity

Academic achievement

Parenting

Confucianism

Culture

\section{A B S TRACT}

Parent-child interactions are influenced by cultural expectations, beliefs, and values. Chinese parenting is shaped by Confucian principles. Chinese children tend to be more academically successful but less creative than American children. Yet, little is known about how actual parent-child interactions might contribute to this finding. We conducted three case studies using a social constructivist approach to parenting to explore how parent-child interactions in early childhood education might influence children's academics and creativity. We studied 11 participants from three families: Chinese, interracial (Chinese mother and American father), and American. Through interviews, observations, and artifacts, we found that parenting decisions are influenced by parents' cultural climates. Chinese parents trained children to learn for academic achievement; American parents encouraged children to pursue their own interests; and interracial parents did some of both.

\section{INTRODUCTION}

Parent-child interactions in early childhood education is critical and impacts children's social development (El Nokali, Bachman, \& Votruba-Drzal, 2010; Valdez, Shewakramani, Goldberg, \& Padilla, 2013) and cognitive development (Ice \& Hoover-Dempsey, 2011). Therefore, academic achievement (Arnold, Zeljo, Doctoroff, \& Ortiz, 2008) and creativity development (Kim, 2016, in press) are also impacted by parent-child interactions in early childhood education. Parent-child interactions are especially critical in developing children's creativity, which starts with facilitating children's self-discovery and often results in valuable and unique innovations as children pursue and excel in what they love most. Creativity development can contribute not only to fulfilling lives but innovation as children utilize their creativity to its full potential to tackle the world's challenges (Kim, 2016). Thus, parents should help children develop their creativity in addition to academics. 
Compared with non-Asian students, more Asian (and Asian American) students are in gifted and talented programs, attend better schools, receive advanced degrees, and become spelling-bee winners or math wizards (Kim, 2016). However, Asian cultural values are negatively associated with creativity (Kim, 2004, 2007, in press; Kim \& Park, in press). Asian parenting can explain children's low creativity compared with Western counterparts (Kim, Lee, Chae, Anderson, \& Laurence, 2011; Kurman, Liem, Ivancovsky, Morio, \& Lee, 2015; Miron-Spektor, Paletz, \& Lee, 2015; Nouri et al., 2015). Asians tend to lack originality and copy others' work (Bartlett \& Fischer, 2011; Schroth, 2012). Only $4.3 \%$ of the total Nobel Prize Laureates are Asians, although Asians constitute $23.4 \%$ of the world population (see Kim, 2016). Therefore, we explored how this might be explained by parent-child interactions across Chinese, interracial, and American parents.

\section{IMPACT OF PARENTING ON CHILDREN'S ACADEMICS AND CREATIVITY}

Chinese families expect children to become experts but use less creative thinking, whereas American families expect children to become innovators. Innovators' family climates differ from those of experts (Albert, 1980a; Dewing, 1970; MacKinnon, 1975), and the key to transforming experts into innovators is early family climates that spark children's curiosity, drive their motivation, and develop their cognitive skills (Albert, 1978). These climates are shaped by family SES, parents' experiences, modeling, and attitudes, their relationships between each other and with their children, and providing children with experiences and educational or career opportunities. These are then influenced by parents' own climates, such as their cultural expectations, beliefs, and values (Kim, 2007, 2009, 2016; Kim et al., 2011). Creative children tend to have highly creative parents (Albert, 1978, 1980b, 1980c; Burks, Jensen, \& Terman, 1930; Cox, 1926; MacKinnon, 1962).

As an example of how parenting is influenced by cultural expectations, beliefs, and values, Chinese parenting is shaped by Confucian principles, which emphasize conformity, unquestioned authority, and filial piety through academic success. These tend to impact children's academic achievement positively but creativity development negatively (e.g., Kim, 2007, 2016, in press; Kim et al., 2011; Kurman et al., 2015; Miron-Spektor et al., 2015; Nouri et al., 2015).

\section{Conformity vs. Diverse Experiences and Viewpoints}

American parents tend to emphasize individualistic values, such as uniqueness, independence, and individuals' choices and interests over the group's; whereas Chinese parents tend to emphasize collectivistic values, such as usefulness (by achieving one's obligations), suppression of self-expression, harmonious relationships, and conformity with the group and the group's interests over individuals interests (e.g., Barkema, Chen, 
George, Luo, \& Tsui, 2015; Miron-Spektor et al., 2015). Children are to avoid expressing their thoughts and emotions, engaging in conflicts or confrontation, and acting different from others, and they are overly concerned with how others view them (Kim et al., 2011; Lu, Huang, \& Chang, 2014; Ma, Doing, Wu, Liang, \& Yin, 2015).

Parents valuing conformity tends to inhibit children from generating many ideas or solutions to open-ended questions or challenges and thinking differently from others, deviating from the norm, or challenging the status quo (Kim, in press; Kim \& Park, in press). This conformity stifles unique perspectives and expressions because an idea must be unique to be creative (Kim, 2016; Sternberg \& Kaufman, 2010; Torrance \& Safter, 1999). Individualistic values are conducive to national innovations, and those cultures that emphasize conformity have resulted in few innovations (Chua, Roth, \& Lemoine, 2015; Gelfand et al., 2011; Kurman, et al., 2015; Rinne, Steel, \& Fairweather, 2012, 2013; Tellis, Prabhu, \& Chandy, 2009). This suggests that creativity requires diverse experiences and viewpoints through exposure to different people and perspectives, as well as discussions and debates in equal relationships, in order to develop critical thinking and open, complex minds (Kim, 2016). This ultimately enables large mental and emotional reservoirs from which one generates many and unique ideas (Feist, 1998; Costa \& McCrae; 1985; McCrae, 1987; Russ, 1993).

\section{Unquestioned Authority vs. Challenging the Authority}

American parents tend to consider their role as facilitative, supportive, or collaborative with children in an equal relationship, whereas Chinese parents tend to consider their role as a controller, who trains children in a hierarchical relationship to fulfill responsibilities in the family (Barkema et al., 2015). They expect children's self-discipline and obedience, as parents are responsible trainers who pass along cultural norms and values to them (Xu, Benson, Mudrey-Camino, \& Steiner, 2010). Chinese parents communicate with children uni-directionally, imposing one viewpoint without discussion, often using physical punishment (Dwairy \& Achoui, 2010). Further, age-related hierarchical norms lead to the expectation that young obey the old (Bae \& Orlinsky, 2006). Parents valuing unquestioned authority tend to (a) limit children's critical thinking, deep thoughts, and complete thought expressions, and (b) cause children to produce quick results through black-andwhite terms, without a thorough understanding of complexity or subtlety (Kim, in press; Kim \& Park, in press). Authoritarian parenting stifles children's creativity (Fearon, Copeland, \& Saxon, 2013; Kim, 2016; Mehrinejad, Rajabimoghadam, \& Tarsafi, 2015; Miller, Lambert, \& Speirs Neumeister, 2012; Mozafari, 2014). Children's experiences of tension or even disturbances, rather than harmony or obedience in family relationships or communication styles, facilitate their creativity development (Albert, 1978; Barron, 1963; 
Brooks, 1973; Dewing \& Taft, 1973; Getzels \& Jackson, 1962; Helson, 1965, 1966; MacKinnon, 1962, 1964, 1967; Morrow \& Wilson, 1961; Roe, 1952; Terman, 1954; Weisberg \& Springer, 1961). Individuals in cultures that emphasize unquestioned authority often expect authoritarian figures to make decisions for them, rather than thinking critically and deeply and then taking initiatives or challenging imposed decisions (Brockner et al., 2001; Morrison \& Milliken, 2000; Pellegrini \& Scandura, 2008). Such cultures have resulted in few innovations (Gelfand et al., 2011; Rinne et al., 2012, 2013; Tellis et al., 2009; Varsakelis, 2001). This suggests that creativity requires one's freedom to think deeply and differently for their unique self-discovery to pursue and excel in what they love and challenge the status quo or authority to magnify the uniqueness of one's future creation (Kim, 2016, 2017, 2018, in press; Kim \& Park, in press).

\section{Selfish Filial Piety by Academic Success vs. Inspiration and Big-Picture Goals}

Filial piety has traditionally been the most essential value among Chinese families. Even as adults, children are expected to remain a part of the family and defer to older family members rather than establishing their own independence (Hwang, 2001). Children are indebted and obligated to their parents, who push children to be academically successful, so that, later, children can financially support aging parents (Bong, 2008; Kim, 2007; Kim et al., 2011; Yang \& Shin, 2008). Most Chinese parents believe children's test scores are the key to future success, so they focus on academic success, even from a young age, while ignoring social and physical development in their children (Jerrim, 2014). Chinese mothers are more involved in the children's academic achievement than American parents are, and they focus on systematic teaching at home (Huntsinger \& Jose, 2009). Most Chinese parents invest in children's private courses and tutoring to prepare for high-stakes tests, regardless of the financial burden on the family (Jerrim, 2014; Tan, Morgan, \& Zagheni, 2016). To repay the debt owed for the parents' sacrifice, children's goals become selfish wealth and high status by all means, rather than selfless ideals for the world (Kim, 2016). To achieve their goals, children often resort to plagiarism in school (Bartlett \& Fischer, 2011; Bong, 2008; Jerrim, 2014; Schroth, 2012; Suen \& Yu, 2006), and children who value filial piety more cheat more often (Bong, 2008).

Chinese parents' narrow focus on academic success, however, undermines the opportunities for other valuable experiences, such as exploring the world outside the school. This focus also leaves little time for children's recreational, physical, or artistic activities, and if they do engage in such activities, drilling is required, rather than selfexpression or enjoyment (Comeau, Huta, \& Liu, 2015). Conversely, guiding children to be committed to achievement in their areas of interest and then passions, rather than just 
memorization for tests facilitates their creativity development (Albert, 1978; Hayes, 1962; Kim, 2016). Asians' unhealthy focus on success led to exam hell (Li \& Wu, 2011), which has existed since China's civil tests system in the 600s (Elman, 2009; Suen \& Yu, 2006). Even after the exam system officially ended in 1905, exam hell continues due to overemphasis on academic achievement, and suicide is the leading cause of death among Asian students (Ahn \& Baek, 2013; Roberts, 2014; Suen \& Yu, 2006; Wang, 2015; Yonngong, 2015). Chinese students experience extreme pressure to score high on tests and memorize textbook information, leaving them no time to explore, question, discuss, or imagine (Chan \& Chen, 2008; Suen \& Yu, 2006).

Parents valuing selfish filial piety stifles children's creativity (Kim, 2016, in press; Kim \& Park, in press). Big-picture goals for patriotism or nationalism increase national innovation, whereas narrow goals for familism or filial piety decrease it (Taylor \& Wilson, 2012). Few innovations have come from those cultures that emphasize selfish filial piety (Brewer \& Venaik, 2011; Taylor \& Wilson, 2012). Creativity requires being inspired by a role model and following curiosity in one's chosen area for big-picture goals, rather than just for family status and wealth, which allows one to transcend concrete constraints and limitations in pursuit of one's goal (e.g., Grant, 2008; Jia, Hirt, \& Karpen, 2009; Liviatan, Trope, \& Liberman, 2008; Polman \& Emich, 2011; Pronin \& Ross, 2006; Thrash, Maruskin, Cassidy, Fryer, \& Ryan, 2010; Wakslak, Trope, Liberman, \& Alony, 2006; Walsh, 2013).

Much attention has been on broader forms of parenting (McBride, Dyer, Liu, Brown, \& Hong, 2009), so there is little research about how parent-child interactions pass on cultural values and contribute to children's academics and creativity. Therefore, we explored how Chinese parent-child interactions in early childhood education reflect such cultural values and how they influence children's academics and creativity differently.

\section{METHOD}

The purpose of this qualitative research was to understand how parents' cultural climates affect parent-child interactions rather than find generalizable results (Johnson \& Christensen, 2012). The aim was to make sense of parent-child interactions through direct personal contact by uncovering parents' cultural expectations, beliefs, and values. We qualitatively explored and compared parent-child interactions across families with different cultural climates that might influence children's academics and creativity. The study was based on the social constructivism approach that posits that individuals derive subjective knowledge and meanings through social interactions and processes when seeking to understand the world in which they live and work, so multiple realities exist and will emerge by studying families from different cultural climates (Creswell, 2013; Mckinley, 2015). We 
explored and compared subjective knowledge and meanings of parents' cultural expectations, beliefs, and values that might influence parent-child interactions and children's daily routine and family rules (Epstein, 2010; Vagle, 2014).

\section{Participants}

Through purposeful sampling, 11 participants were identified. We treated each family as a unit in the sample, and each father, mother and child as a participant (Table 1). The sampling criterion was children who were three to six years old whose parents were from one of the three cultural climates: (a) Chinese immigrant parents living in the U.S., (b) Chinese immigrant mother and American father experiencing two cultures at home, and (c) American parents. All parents were highly educated, holding at least a bachelor's degree. We interviewed the parents and observed children via videotapes provided by the parents.

Table 1

\section{Children's Age $(\mathbf{N}=5)$ and Parents' Educational and Professional Backgrounds $(\mathrm{N}=6)$ for Three Families}

\begin{tabular}{|c|c|c|c|c|c|c|}
\hline Family & \multicolumn{2}{|c|}{ Chinese } & \multicolumn{2}{|c|}{ Inter-racial } & \multicolumn{2}{|c|}{ American } \\
\hline \multirow[t]{2}{*}{ Child's age } & \multirow{2}{*}{\multicolumn{2}{|c|}{$\begin{array}{l}\text { 4-year-old daughter } \\
\text { 1-year-old son }\end{array}$}} & \multicolumn{2}{|c|}{ 5-year-old son } & \multicolumn{2}{|c|}{ 5-year-old son } \\
\hline & & & & & \multicolumn{2}{|c|}{ 2-year-old daughter } \\
\hline Background & Mother & Father & Mother & Father & Mother & Father \\
\hline Educational & Bachelor's & Ph.D. candidate & Master's & Bachelor's & Ph.D. & Ph.D. candidate \\
\hline Professional & Housewife & Student & Teacher & Retired & Art Conservator & Student \\
\hline
\end{tabular}

\section{Data Collection}

Data were gathered in four parts: First, we interviewed (semi-structured) each parent, focusing on parent-child interactions and parent's cultural climates, including their values, beliefs, and expectations for the interactions. Field notes were taken during the interviews, and voice recordings were transcribed. Second, we examined and photographed artifacts and educational documents and objects, including books, DVDs, toys, musical instruments, family videos, traveling photos, and iPad applications provided by the parents. Third, we observed parent-child interactions on video clips that the parents provided, including several 30-minutes video clips of parents playing, reading, or talking with the child (ren). Fourth, we examined the artifacts and interviewed (follow-up) each parent, focusing on the questions raised from observing the parent-child interactions, including reasons behind the words and behaviors during the interactions. Last, we interviewed (final) each parent for accuracy checking for the summaries of the interviews and video watching. 


\section{Data Analysis}

First, we coded the concepts and analyzed the data after the first interviews and continued this process throughout each phase of data collection within the study. As qualitative research is an emergent process, the data were dynamic, and based on the parents' responses and feedback, revisions occurred throughout data collection and analysis of this study (Creswell, 2002). Second, we grouped the actual data gathered into meaningful units and ensured that the original intent of each response had not been compromised by the meaning derived. Third, the aggregate meanings were then condensed and grouped into themes, categories, and sub-categories to identify related themes that appeared throughout the data (Johnson \& Christensen, 2012). Fourth, several themes were identified or differentiated, which led to the need for further clarification or more detailed information, and then more grouping until data saturation had been achieved (Guest, Bunce, \& Johnson, 2006). Fifth, the themes were compared to the original responses to ensure that something significant in the original responses had not been left out in the groupings or that the grouping created something that is not in the original responses. Using a structural description, we sought to identify all possible knowledge and meanings for a rich descriptive narrative about parent-child interactions (Creswell, 1998).

The evaluation criteria (Lincoln \& Guba, 1985) for the study carried out in accordance with the approach of social constructivism were (a) credibility, (b) generalizability, and (c) dependability and confirmability (accounting for the study process and products). Credibility. Credibility was enhanced using verification, prolonged engagement and observation, and triangulation. During the interviews, we asked the parents, "Is this what you meant?" to verify their values, beliefs, and expectations. Three to four hours of interviews allowed for deep engagement. Observing parent-child interactions served to triangulate the audiotape recording of the interviews.

Generalizability. Although generalizable results were not the purpose of this study, the findings were compared with related studies on cultural climates. We documented the knowledge and meanings of parent-child interactions to enable others to make judgements of the generalizability of the study findings.

Dependability and confirmability. We created an audit trail, documenting the study proposal, the steps taken before, during, and after the interviews, along with our notes of the parents' proceedings, the coding and analysis of the interview transcripts, the working drafts of the emerging cultural climates and the final version of the derived cultural climates (Lincoln \& Guba, 1985). 


\section{RESULTS}

Results revealed that parent-child interactions can be depicted through three main themes: (a) parents' cultural climates, such as their values, beliefs, and expectations, 2) home climates, such as learning environments, language uses, daily routines, family rules, and toys, and 3) parental involvement in child's activities, such as homework help, reading time, play time, and extra-curricular activities. We found five similarities in the themes of parent-child interactions. First, all parents emphasized that their own parents' parenting (either as adaptation or rejection) greatly influenced their parenting, which in turn reflected their cultural climates. Second, they tried to build a structured life for children to form good habits, using repetition and reminders as the main parenting methods. Third, they emphasized the importance of reading for preschool children. Fourth, during daily routines, families had time for reading, watching videos, and playing together. Finally, all of the families regarded video or TV watching as having negative effects on children, so they enforced time limits and carefully chose appropriate programs for children. We also found the following differences in the parent-child interaction themes:

\section{The Chinese family}

In the Chinese family, the mother was responsible for educating the children and made all decisions for them even when the parents' opinions conflicted. The father's role was minimal, and he rarely played with the children, though he helped them study when necessary. The dad reported that his father had never been involved in his education, but he was academically self-motivated because he desired to be like his father who demonstrated authority in front of the children. He also reported that although he wanted to be friends with his children, he instead focused on maintaining authority over the children in order to prevent their misbehaviors, including a lack of effort in learning.

The mother reported that she occasionally used physical punishment to discipline her children's misbehaviors, modeling after her father. She reported learning a lot from American disciplining methods, and that since she learned about time-out, she used both time-out and physical punishment to discipline the children and keep her authority. She focused on academic success and emphasized the family rule that her children should be focused and persistent during any learning. Except this rule and the no TV rule, she did not have other family rules (Table 2). The parents valued structured-learning activities and persistence for these activities. When the daughter did not perform well in her ballet class, the mother criticized her daughter's failure to follow the teacher's instructions and compelled her to focus and persist. Reading was also one of the structured-learning activities. When she found her daughter was unfocused while being read to, she made her 
listen by telling her, If you don't concentrate, I will stop reading or by reading loudly. She repeatedly emphasized the importance of children's academic success that required both parents to participate in children's reading time to make sure the children learn what they are supposed to learn. The family paid beyond their budget for the children's preschool education. She had asked other parents with older children about high-quality preschools before enrolling her children in an expensive preschool. She reported that she would provide her children with many learning opportunities, including piano, when the family's financial situation improved.

Table 2

Family Rules and Consequences for Children in the Three Families

\begin{tabular}{|c|c|c|c|}
\hline Family & Chinese & Inter-racial & American \\
\hline Consequences & $\begin{array}{l}\text { - Be focused and per- } \\
\text { sistent during any } \\
\text { learning } \\
\text { - No TV }\end{array}$ & $\begin{array}{l}\text { - Mother: No pun- } \\
\text { ishment } \\
\text {-Father: Physical } \\
\text { punishment }\end{array}$ & $\begin{array}{l}\text { - One-hour of TV watching } \\
\text { - Eat in the kitchen } \\
\text { - No Coke and soda } \\
\text { - Ask to be excused if they finish eating but } \\
\text { others haven't } \\
\text { - Dessert after dinner only on Friday, Sat- } \\
\text { urday, and Sunday nights } \\
\text { - Choose one treat in grocery store and } \\
\text { share with others after taking home } \\
\text { - No ball throwing in the house } \\
\text {-No biting and no fighting } \\
\text { - No interruptions if someone else is talking } \\
\text { - Children get up if the clock turns green } \\
\text { - Specific consequences of choices }\end{array}$ \\
\hline
\end{tabular}

The family had fewer books (e.g., about 20 books) and fewer toys requiring physical activities, yet had more educational materials that help children's learning at home and more frequent library visits than the other two families. The parents considered extracurricular activities as extra-school classes for later career opportunities. The mother reported that she made all decisions for her children's extra-learning classes because (a) the children are too young to make decisions; (b) she wanted to provide such opportunities that she could not have; and most importantly, (c) these would bring the children many career opportunities later in life, which she repeatedly emphasized.

The parents reported that they became Christians in college. The father took the children to a bible study on Friday nights and church on Sunday mornings. He reported 
that although God taught him never to be angry or yell at the children, sometimes disciplining children required such behaviors. The mother often told her children to pray to God when any problems arose. She reported that her religious beliefs confirmed being a homemaker and taking care of children as important as having a successful career outside of the home.

The parents required the four-year old daughter to speak Chinese at home to maintain her parents' native language. Her teacher suggested the mother take her daughter to a speech therapist because she did not speak or play with her classmates. However, neither parent saw a problem because she was simply not ready to interact with classmates. The mother advised the teachers to be patient, as her daughter would improve. When the teacher reported the daughter never spoke at school, the parents questioned the daughter and asked why she never spoke at school. Then, they pushed her to speak English more than Chinese, and the father borrowed English books from the library to help her improve. When the daughter felt irritated due to the pressure from the parents, however, they stopped pushing her to speak any specific language at home. The mother reported that Americans are so nervous about children's problems that are not real problems and will be solved by effort that many children become labeled with speech problem, social problem, and ADHD, actually resulting in children's problems.

\section{The Interracial family}

Although the parents had different cultural climates in the interracial family, they reported rarely having conflicts about parenting because the father followed the Chinese way: pushing children for academic success. The mother reported that she, as a Chinese parent, had to put high values on children's academic success. She reported that she followed her mother's parenting in which children must be academically successful, starting in early childhood. The mother reported that she spent every weekend doing things with her son because her interaction time during the week was limited. She followed her no spanking ever rule as a rejection of her mother's parenting that used frequent spanking, which she thought was ineffective in improving her behavior. However, the father thought occasional physical punishment was necessary for a strong-willed child, like his son.

Both parents had high expectations for their children's academic success. Because the father had two additional grown children from his previous marriage, he expected his young son to be as successful as his other children. He emphasized higher expectation, higher achievement. The parents wanted the son to study science in college to earn a good income after graduation. Because they desired a successful life for him, they emphasized the importance of reading and math and arranged specific learning ac- 
tivities as his daily routine. The father believed parent-child interactions for teaching and learning were important because parents not only play a supplemental role for schoolteachers but also learn from the child. The father asked his son about his activities in preschool every day on the way home. Because the father learned from working with his father in the garage, he used the same method to teach his son. He sometimes included the son in housework, such as planting seeds and vacuuming. The parents thought the son was too young to take extracurricular classes, such as swimming and piano. Instead, they signed him up for a soccer team, but he dropped it because he did not like interacting with strangers. They introduced him to other sports and skills, and visited museums and parks on weekends.

The mother neither spoke Chinese nor taught her son Chinese at home. Both parents emphasized the importance of reading books in English and started reading to their son at an early age. Because the kindergarten teachers sent emails to parents about the son's daily learning, the mother borrowed books related to the curriculum from the library and read to him. Only the father read books to the son because, the father reported, he does not have a foreign accent like the mother has when reading books. He read a series of books to his son because he judged them to be classics. He had 15 to 30 minutes to read before bedtime nightly. During reading, the mother tested her son's comprehension by quizzing him for the right answers.

The parents reported that they wanted their son to have rich cultural experiences and friendships with peers from different backgrounds and provided him with diverse exposures to many places. The mother believed that toys are important for her son's cognitive development, and the family had a buy one toy when shopping rule (Table 2). The family had a greater variety and amount of toys than the other two families. They had more toys requiring physical activities, such as balls and a trampoline, than the Chinese family but fewer than the American family. They had more books (e.g., about 150 books), especially preschool workbooks and textbooks for future use. The parents reported that they place high value on their son's environment for academic success including preschool curriculum and resources. The mother reported that following her mother's cultural parenting, she also encouraged her son to be academically driven. She reported encouraging her son's independence, but her action showed differently: She followed him closely while he was on the playground; prepared toys for her son to share with his preschool classmates; selected his outfits daily, believing appearance is very important in life; and calculated the minutes of each of her son's activities after dinner. 


\section{The American family}

Both parents in the American family reported they had developed their autonomy since they were young. The mother followed her own mother's parenting methods, such as allowing the children to try different things without worry. Both respected their children's choices, even their two-year old daughter's, by sharing the consequences of choices and letting the children make decisions independently. The father regarded consequences of misbehavior as an important parenting method. The family had more family rules, including rules for eating, sleeping, and playing, for their children than the other two families (Table 2). The mother followed some of her parents' rules, such as no coke and soda for children. The family had specific arrangements for the children after returning from preschool, such as requiring them to clean the shared room where they play daily.

The parents had no specific educational expectations for the children's future as the other two families had, such as academic success. They reported that they were unwilling to impose their personal expectations on the children's aspirations, and instead, provided them with a nurturing environment, where they could pursue their own interests and genuinely enjoy learning. The mother reported that she considered early childhood education as more about parent-child interactions than organized education. Because she believed each parent-child interaction itself is meaningful, she reported spending as much time with her children as she could, traveling from her work and home to have lunch with her children every day. She wished her children would not have so much homework in preschool and kindergarten so that families could spend more time together. The parents believed in children learning important life skills and citizenship during this time, such as sharing and swimming. The father reported that his own father taught him sharing and equality through the interactions between him and both his parents and sister, which he taught to his children.

The father reported a memory of disappointment when he asked his parents questions, and they answered, "It's magic." He believed parents must answer all of the children's questions. He took his children's questions very seriously to encourage their curiosity and autonomy. The parents often took the children to the park, and the children climbed trees and watched animals so the children could appreciate and be close to nature. Although the family was unable to frequently travel due to the mother's breast feeding, the parents hope to take them to museums when the children get older. The parents conceptualized extra-curricular activities as children's out-of-school activities, such as exploring and interacting with nature. The family raised chicks so the children could observe animals' lives, and had more toys requiring physical activities (e.g., balls, a scooter, a bi- 
cycle, etc.) than the other two families.

Before the son started kindergarten, the father took him to different parent-child activities in the community, such as music, reading, and swimming classes, to interact with his son in various ways. The parents included both children in cooking, believing it was a good learning opportunity for them, and the children showed strong interests in and enjoyment of it.

Although the parents believed reading and math practice could prepare the children for kindergarten, they emphasized that knowledge should be appropriate to the children's age. They did not have structured-learning activities at home, yet the parents used flash cards to teach the children math when they showed interest. They had about 70 books (more than the Chinese family but fewer than the interracial family) and included family books but no children's workbooks or future textbooks. They reported that they grew up believing reading was important because both of their parents' family members shared many children's books with them. They reported that they read for fun and love reading, and read to the children three times every day. Sometimes the children read by themselves, always choosing books independently.

Both parents lived for two years in a region of Canada, where French is an official language, and the father also lived in Egypt for six years and can speak Arabic to a limited degree. They reported definitely supporting the children learning a second language. Both parents attended Montessori preschools and send their own children to a Montessori school. The mother believed that preschool is more effective for children's learning than parents' teaching, so preschool teachers should regard themselves as teachers, not babysitters. He also believed preschool is not a warehouse of children, but a nurturing environment where children can learn something. The parents valued individual differences and accepted each child's different challenges, such as learning difficulties. When one of the son's teachers noticed slurred words in his speech and suggested the parents should provide him with speech therapy, they did so, despite not thinking it was serious. Afterwards, the speech therapist required them to help him with pronunciation practice every day. Because they did not want the son to experience challenges with talking to teachers or friends in the future, they took him to the therapy and practiced with him. They were confident the therapy and practice would cure him.

The mother reported being raised in a religious family, which caused her to be rebellious and have behavior problems due to the rigid, strict family atmosphere. She said, forcing your kids to do intense things could make them want to do nothing, and could just push them to be exactly the opposite of what you are trying to make them do. Because of 
her negative experience, she said she would not force her children to be religious or to do anything they did not want to do.

\section{DISCUSSION}

Three main themes of parent-child interactions emerged: parents' cultural climates, home climates, and parental involvement in the children's activities. We found that parents' cultural climates, such as their values, beliefs, and expectations, shape their views of parental roles in child-rearing, which are influenced by their own parents' parenting. We also found that parents' cultural climates influence their involvement in child's activities, such as talking with children about the school day on the way home, having meals with children, taking children to parks and museums, and playing with children, in addition to homework help, reading time, play time, and extra-curricular activities. We found different cultural climates among the three families.

\section{Conformity: Gender-role Expectations and Not Being Different}

We found that Chinese parents believe the mother must be more involved in parenting than the father, whereas American parents emphasize equal responsibilities between two parents. The American parents took turns playing with the children and the American father said, I don't expect that mom should provide emotional support, and dad should be teaching how to play sports. The Chinese family's belief in gender roles in parenting is mirrored by previous research findings regarding Asians' adherence to conformity to genderrole expectations (Kim, 2007, 2016; Kim et al., 2011). However, creativity requires both traditionally feminine (e.g., sensitivity and softness) and male (e.g., independence and toughness) characteristics. Gender-bias-free roles and interests, as well as learning from both parents' skills and strengths, must be encouraged (Kim, 2016; Kim \& Park, in press).

We found that Chinese parents disregard individual differences and ignore children's different challenges, including learning difficulties, insisting that the child's effort will overcome them, whereas American parents value individual differences and accept children's different challenges and help the child overcome them. The Chinese parents' reaction to their daughter's speech and social problems is explained by previous research findings that Asians tend to conform to the norm to not appear different and hide or deny one's disability because they are sensitive to social approval and disapproval and want to avoid feeling blamed (e.g., Chiang \& Hadadian, 2009; Kim-Rupnow, 2005; McCabe, 2007; Yan, Kim, Kang, \& Wilkerson, 2017). Moreover, Chinese parents tend to feel shame, social stigma, sorrow, denial, or anger about their child's disability (McCabe, 2007; Yan et al., 2017). They expect a negative future from a child with disability, including low academic achievement (Lee \& Kim, 2005). Even worse, some feel helpless and de- 
pressed because they view their child's disability as God's punishment for their own bad karma, such as their poor parenting, wrongdoing, or breaking cultural norms in the past or previous life (e.g., Chiang \& Hadadian, 2009; Kim-Rupnow, 2005; Palawat \& May, 2012). Conformity pressures stifle unique perspectives and expressions required for creativity. Innovation must go beyond current knowledge through nonconformity, individuality, and originality, so the ability to think freely and differently, to deviate from the norm, and to challenge the status quo must be promoted (Kim, 2016, in press; Kim \& Park, in press).

We found that American parents consider diverse viewpoints, such as a different religious view and the teacher's view on their son's disability, even when they disagree with the view, whereas Chinese parents insist on their own view of religion and daughter's disability. Creativity requires openness to diverse experiences and viewpoints through discussions and debates in order to compromise, collaborate, and go beyond the existing boundaries to imagine something new (Kim, 2016, in press; Kim \& Park, in press).

\section{Unquestioned Authority}

We found that Chinese parents use unquestioned authority as a parenting method and use physical punishment to discipline children, whereas American parents set clear family rules and expectations for the children in equal relationships, valuing children's autonomy, personal choice, independent decision making, and learning from consequences. This is consistent with previous findings that Asians tend to control children to fulfill their responsibilities in hierarchical relationships and consider their role as a controller who trains children (Barkema et al., 2015; Leung, Wong, Wong, \& McBride-Chang, 2010; Park \& Chesla, 2007; McNeely \& Barber, 2010; Williams, Barclay, \& Schmied, 2004). We found that American parents facilitate their children's learning, whereas Chinese parents train children to academically succeed by relying on physical punishment and demanding children's obedience. We found that American parents develop children's knowledge of equality through parent-child interactions and sibling interactions and use family rules for good habits, citizenships, and life skills, which is consistent with the American social value of equality since American society was founded upon democracy (Fowler, 2013). In contrast, Chinese society was founded on hierarchy, which is also consistent with previous findings that Asians tend to demand children's self-discipline, respect for unquestioned authority, and obedience, often using punitive practices (Cui et al., 2016; Dwairy \& Achoui, 2010; Kim, 2016; Schneider \& Lee, 1990; Steinberg, Dombusch, \& Brown, 1992). However, those cultures, including Asian, valuing unquestioned authority and obedience to authority have also resulted in few innovations (Gelfand et al., 2011; Rinne et 
al., 2012, 2013). Creativity requires one to make decisions, take initiatives, and face challenges early, instead of depending on authoritarian figures (Kim, 2016).

\section{Selfish Filial Piety by Academic Success}

Although the American father in the interracial family says he follows Chinese parenting, emphasizing children's academic success, he also follows his own father's parenting, like teaching children how things work. We found that Chinese parents focus on children's academic success by focus, effort, and persistence, and use family rules mainly for academics, whereas American parents emphasize children's curiosity, interests, and strengths. This is consistent with previous findings that Chinese parents emphasize children's focus and persistence for academic success while investing parents' time and money in the success (Jerrim, 2014). However, teaching children that the only endeavor worth putting effort and persistence into is academic success inhibits their self-efficacy on and persistence for what they love to do by never giving children the chance to love doing anything (Kim, 2016, in press).

We also found that Chinese parents consider extra-curricular activities as extraschool classes for later career opportunities, whereas American parents consider them as out-of-school activities like interacting with nature. Further, Chinese parents provide children with fewer toys requiring physical activities and more learning materials, whereas American parents provide more toys requiring physical activities and fewer learning materials. This is consistent with previous findings that Asians tend to tie their sense of selfworth to the wealth and high status resulting from academic success, which is the way children demonstrate filial piety to repay the debt they owe for their parents' sacrifices (Bang \& Montgomery, 2013; Bong, 2008; Marginson, 2011). We also found that Chinese parents value structured-learning activities with workbooks and future textbooks, and reading was an activity for learning, whereas American parents encourage children's curiosity and value doing activities together, with no workbooks or future textbooks, and reading was an activity for fun. This is consistent with previous findings that Chinese consider learning, including reading, for academic success, rather than learning and reading for curiosity and enjoyment (Comeau et al., 2015). Creativity requires following curiosity in one's chosen topic and one to be inspired by unselfish, big-picture goals, such as patriotism, nationalism, and humanitarianism, rather than selfish goals, which enables one to transcend constraints and limitations and eventually achieve innovation (e.g., Brewer \& Venaik, 2011; Taylor \& Wilson, 2012).

\section{Limitations and Conclusions}

A limitation of the study is its small sample size of families, and we acknowledge that studying a few parents does not warrant making causative inferences for cross-cultural 
comparisons. We do not claim that the three families in this study represent all Chinese, interracial, or American families. We recommend that future studies replicate this study with larger sample sizes of diverse populations. We suggest that future studies investigate how parents develop children's creativity across different cultural climates.

Despite the limitations, we hope this study can provide parents with a snapshot of how parent-child interactions might play a role in children's academic achievement and creativity development. Chinese parent-child interactions may foster children's academic success, but it stifles children's desire for learning and developing creativity. In contrast, American parent-child interactions may foster children's creativity by focusing more on learning rather than just academic success.

\section{REFERENCES}

Albert, R. S. (1978). Observations and suggestions regarding giftedness, familial influence, and the achievement of eminence. Gifted Child Quarterly, 22, 201-211.

Albert, R. S. (1980a). Exceptionally gifted boys and their parents: Basic educational, cognitive, and creative similarities. Gifted Child Quarterly, 24, 174-179.

Albert, R. S. (1980b). Family positions and the attainment of eminence: study of positions and special family experiences. Gifted Child Quarterly, 24, 87-95.

Albert, R. S. (1980c). Genius. In. R.H. Woody (Ed.), The encyclopaedia of clinical assessment. San Francisco, CA: Jessey-Bass.

Ahn, S. Y., \& Baek, H. J. (2013). Academic achievement-oriented society and its relationship to the psychological well-being of Korean adolescents. In C-C. Yi (Ed.), The psychological well-being of East Asian youth, V. 2 of Quality of life in Asia (pp. 265279). Dordrecht, The Netherlands: Springer.

Arnold, D. H., Zeljo, A., Doctoroff, G. L., \& Ortiz, C. (2008). Parent involvement in preschool: Predictors and the relation of involvement to preliteracy development. School Psychology Review, 37, 74-90.

Bae, S. H., \& Orlinsky, D. E. (2006). Gender, marital status, and age in the professional development of psychotherapists in Korea. Asian Journal of Women's Studies, 12(1), 36-62.

Bang, H., \& Montgomery, D. (2013). Wisdom and ego-identity for Korean and American late adolescents. Journal of Cross-Cultural Psychology, 44, 807-831.

Barkema, H. G., Chen, X. P., George, G., Luo, Y., \& Tsui, A. S. (2015). West meets east: New concepts and theories. Academy of Management Journal, 58, 460-479.

Barron, F. (1963). Creativity and psychological health: Origins of personal vitality and creative freedom. New York, NY: Van Nostrand. 
Bartlett, T., \& Fischer, K. (2011). The China conundrum. The Chronicle of Higher Education. Retrieved from http://chronicle.com/article/The-China-Conundrum/129628/

Bong, M. (2008). Effects of parent-child relationships and classroom goal structures on motivation, help-seeking avoidance, and cheating. Journal of Experimental Education, 76, 191-217.

Brewer, P., \& Venaik, S. (2011). Individualism-collectivism in Hofstede and GLOBE. Journal of International Business Studies, 42, 436-445.

Brockner, J., Ackerman, G., Greenberg, J., Gelfand, M. J., Francesco, A. M., Chen, Z. X., \& Kirkman, B. L. (2001). Culture and procedural justice: The influence of power distance on reactions to voice. Journal of Experimental Social Psychology 37, 300-315.

Brooks, J. B. (1973). Familial antecedents and adult correlates of artistic interests in childhood. Journal of Personality, 41, 110-120.

Burks, B. S., Jensen, D. W., \& Terman, L. M. (1930). The promise of youth: Vol. 3: Genetic studies of genius. Stanford, CA: Stanford University Press.

Chan, J., \& Chen, Y. (2008). Processes and outcomes of encouraging universities to implement creative studies colleges. In J. Chan. (Ed.), Creative education programs in Taiwan: Development and implementation (pp. 244-257). Taipei, Taiwan: Ministry of Education.

Chiang, H. L., \& Hadadian, A. (2009). Chinese and Chinese- American families of children with disabilities. International Journal of Special Education, 22(2), 19-23.

Chua, R. Y., Roth, Y., \& Lemoine, J. F. (2015). The impact of culture on creativity: How cultural tightness and cultural distance affect global innovation crowdsourcing work. Administrative Science Quarterly, 60, 189-227.

Comeau, G., Huta, V., \& Liu, Y. (2015). Work ethic, motivation, and parental influences in Chinese and North American children learning to play the piano. International Journal of Music Education, 33, 181-194.

Costa, P. T, Jr., \& McCrae, R. R. (1985). The NEO Personality Inventory manual. Odessa, FL: Psychological Assessment Resources.

Cox, C. M. (1926). The early mental traits of 300 geniuses. In Vol. 2 of Genetic studies of genius. Stanford, CA: Stanford University Press.

Creswell, J. W. (1998). Qualitative inquiry and research design: Choosing among five traditions. Thousand Oaks, CA: Sage.

Creswell, J. W. (2002). Educational research: Planning, conducting, and evaluating quantitative and qualitative research. Upper Saddle River, NJ: Merrill Prentice Hall.

Creswell, J. W. (2013). Qualitative inquiry \& research design: Choosing among five approaches (3rd ed.). Los Angeles, CA: Sage. 
Cui, N., Xue, J., Connolly, C. A., \& Liu, J. (2016). Does the gender of parent or child matter in child maltreatment in China? Child Abuse \& Neglect, 54, 1-9.

Dewing, K. (1970). Family influence on creativity: A review and discussion. Journal of Special Education, 4, 399-404.

Dewing, K., \& Taft, R. (1973). Some characteristics of the parents of creative twelve-yearolds. Journal of Personality, 41, 71-85.

Dwairy, M., \& Achoui, M. (2010). Parental control: A second cross-cultural research on parenting and psychological adjustment of children. Journal of Child and Family Studies, 19, 16-22.

El Nokali, N. E., Bachman, H. J., \& Votruba-Drzal, E. (2010). Parent involvement and children's academic and social development in elementary school. Child Development, 81, 988-1005.

Elman, B. A. (2009). Civil service examinations (Keju). In Berkshire encyclopedia of China (pp. 405-410). Great Barrington, MA: Berkshire.

Epstein, J. L. (2010). School/ Family/Community Partnerships: Caring for the children we share. Phi Delta Kappan, 92, 81-96.

Fearon, D. D., Copeland, D., \& Saxon, T. F. (2013). The relationship between parenting styles and creativity in a sample of Jamaican children. Creativity Research Journal, 25, 119-128.

Feist, G. J. (1998). A meta-analysis of personality in scientific and artistic creativity. Personality and Social Psychology Review, 2, 290-309.

Fowler, F. C. (2013). Policy studies for educational leaders: An introduction (4 ${ }^{\text {th }}$ ed.). Upper Saddle River, NJ: Pearson Education.

Gelfand, M. J., Raver, J. L., Nishii, L., Leslie, L. M., Lun, J., Lim, B. C., . . Aycan, Z. (2011). Differences between tight and loose cultures: A 33-nation study. Science, 332, 1100-1104.

Getzels, J. W., \& Jackson, P. W. (1962). Creativity and intelligence. New York, NY: Wiley. Grant, A. M. (2008). Does intrinsic motivation fuel the prosocial fire? Motivational synergy in predicting persistence, performance, and productivity. Journal of Applied Psychology, 93, 48-58.

Guest, G., Bunce, A., \& Johnson, L. (2006). How many interviews are enough? An experiment with data saturation and variability. Field Methods, 18(1), 59-82.

Hayes, K. J. (1962). Genes, drives, and intellect. Psychological Reports, 10, 299-342.

Helson, R. (1965). Childhood interest clusters related to creativity in women. Journal of Consulting Psychology, 29, 352-361. 
Helson, R. (1966). Personality of women with imaginative and artistic interests; The role of masculinity, originality, and other characteristics in their creativity. Journal of Personality, 34, 1-25.

Huntsinger, C. S., \& Jose, P. E. (2009). Parental involvement in children's schooling: Different meanings in different cultures. Early Childhood Research Quarterly, 24, 398-410.

Hwang, K.-K. (2001). The deep structure of Confucianism: A social psychological approach. Asian Philosophy, 11, 179-204.

Ice, C. L., \& Hoover-Dempsey, K. V. (2011). Linking parental motivations for involvement and student proximal achievement outcomes in homeschooling and public schooling settings. Education \& Urban Society, 43, 339-369.

Jerrim, J. (2014). Why do East Asian children perform so well in PISA? An investigation of Western-born children of East Asian descent. London, UK: University of London.

Jia, L., Hirt, E. R., \& Karpen, S. C. (2009). Lessons from a faraway land: The effect of spatial distance on creative cognition. Journal of Experimental Social Psychology, 45, 1127-1131.

Johnson, B., \& Christensen, L. (2012). Educational research: Quantitative, qualitative, and mixed approaches. 4th ed. Thousand Oaks, CA: Sage.

Kim, K. H. (2007). Exploring the interactions between Asian culture (Confucianism) and creativity. Journal of Creative Behavior, 41, 28-54.

Kim, K. H. (2009). Cultural influence on creativity: The relationship between Asian culture (Confucianism) and creativity among Korean educators. Journal of Creative Behavior, 43, 73-93.

Kim, K. H. (2016). The creativity challenge: How we can recapture American innovation. Amherst, NY: Prometheus Books.

Kim, K. H. (2017). The Torrance Tests of Creative Thinking Figural or Verbal: Which one should we use? Creativity: Theories-Research-Applications, 4, 302-321.

Kim, K. H. (2018). How can parents and teachers cultivate creative climates for children to become innovators? Childhood Education, 94(2), 10-17. DOI: 10.1515/ctra-2017-0015

Kim, K. H. (in press). Creativity crisis update: America follows Asia in pursuing high test scores over learning. Roeper Review.

Kim, K.H., Lee, H. E., Chae, K., Anderson, L., \& Laurence, C. (2011). Creativity and Confucianism among American and Korean educators. Creativity Research Journal, 23, 357-371.

Kim, K.H., \& Park S. G. (in press). How do parents' cultural values affect children's creativity? Creativity Research Journal. 
Kim-Rupnow, W. S. (2005). Disability and Korean culture. In J. H. Stone (Ed.), Culture and disability: Providing culturally competent services (pp. 115-138). Thousand Oaks, CA: Sage.

Kurman, J., Liem, G. A., Ivancovsky, T., Morio, H., \& Lee, J. (2015). Regulatory focus as an explanatory variable for cross-cultural differences in achievement-related behavior. Journal of Cross-Cultural Psychology, 46, 171-190.

Lee, H. S., \& Kim, J. N. (2005). A study on expectation of parents of children with autism spectrum disorders. Journal of Special Education \& Rehabilitation Science, 44, 175-193.

Leung, A. N., Wong, S. S., Wong, I. W., \& McBride-Chang, C. (2010). Filial piety and psychosocial adjustment in Hong Kong Chinese early adolescents. Journal of Early Adolescence, 30, 651-667.

Li, C., \& Wu, J. (2011). The structural relationships between optimism and innovative behavior: Understanding potential antecedents and mediating effects. Creativity $R e-$ search Journal, 23, 119-128.

Lincoln, Y. S., \& Guba, E. G. (1985). Naturalistic inquiry. Newbury Park, CA: Sage.

Mansyur, C. L., Liviatan, I., Trope, Y., \& Liberman, N. (2008). Interpersonal similarity as a social_distance dimension: A construal level approach to the mental representations_and judgments of similar and dissimilar others' actions. Journal of Experimental_Social Psychology, 44, 1256-1269.

Lu, L., Huang, Y., \& Chang, H. (2014). Confucian dynamism, the role of money and consumer ethical beliefs: An exploratory study in Taiwan. Ethics and Behavior 24, 34-52.

Ma, Z., Doing, W., Wu, J., Liang, D., \& Yin, X. (2015). Confucian ideal personality and Chinese business negotiation styles: An indigenous perspective. Group Decision and Negotiation, 24, 383-400.

Marginson, S. (2011). Higher education in East Asia and Singapore: Rise of the Confucian model. Higher Education, 61, 587-611.

McBride, B. A., Dyer, W. J., Liu, Y., Brown, G. L., \& Hong, S. (2009). The differential impact of early father and mother involvement on later student achievement. Journal of educational psychology, 101, 498-508.

McCabe, H. (2007). Parent advocacy in the face of adversity: Autism and families in the People's Republic of China. Focus on Autism and Other Developmental Disabilities, 22, 39-50.

McCrae, R. M. (1987). Creativity, divergent thinking, and openness to experience. Journal of Personality and Social Psychology, 52, 1258-1265. 
McKinley, J. (2015). Critical argument and writer identity: Social constructivism as a theoretical framework for EFL academic writing. Critical in Language Studies, 12, 184-207.

MacKinnon, D. W. (1962). The nature and nurture of creative talent. American Psychologist, 17, 484-495.

MacKinnon, D. W. (1964). Creativity and images of the self. In R. W. White (Ed.), The study of lives. New York, NY: Atherton Press.

MacKinnon, D. W. (1967). Assessing creative persons. Journal of Creative Behavior, 1, 291-304.

MacKinnon, D. W. (1975). IPAR's contribution to the conceptualization and study of creativity. In Taylor, I. \& Getzels, J. (Eds.) Perspectives in Creativity. Chicago, IL: Aldine.

McNeely, C. A., \& Barber, B. K. (2010). How do parents make adolescents feel loved? Perspectives on supportive parenting from adolescents in 12 cultures. Journal of Adolescent Research, 25, 601-631.

Mehrinejad, S. A., Rajabimoghadam, S., \& Tarsafi, M. (2015). The relationship between parenting styles and creativity and the predictability of creativity by parenting styles. Procedia - Social and Behavioral Sciences, 205, 56-60.

Miller, A. L., Lambert, A. D., \& Speirs Neumeister, K. L. (2012). Parenting style, perfectionism, and creativity in high-ability and high-achieving young adults. Journal for the Education of the Gifted, 35, 344-365.

Miron-Spektor, E., Paletz, S. B., \& Lin, C. C. (2015). To create without losing face: The effects of face cultural logic and social-image affirmation on creativity. Journal of Organizational Behavior, 36, 919-943.

Morrison, E. W., \& Milliken, F. J. (2000). Organizational silence: A barrier to change and development in a pluralistic world. Academy of Management Review, 25, 706-725.

Morrow, W. R., \& Wilson, R. C. (1961). Family relations of bright high-achieving and under-achieving high school boys. Child Development, 32, 501-510.

Mozafari, S. (2014). Prediction of creativity and academic achievement based on child rearing styles. International Journal of Psychology and Behavioral Research, 3, 166-176.

Nouri, R., Erez, M., Lee, C., Liang, J., Bannister, B. D., \& Chiu, W. (2015). Social context: Key to understanding culture's effects on creativity. Journal of Organizational Behavior, 36, 899-918.

Palawat, M., \& May, M. E. (2012). The impact of cultural diversity on special education provision in the United States. Journal of the International Association of Special Education, 13(1), 58-63. 
Park, M., \& Chesla, C. (2007). Revisiting Confucianism as a conceptual framework for Asian family study. Journal of Family Nursing 13, 293-311.

Polman, E., \& Emich, K. J. (2011). Decisions for others are more creative than decisions for the self. Personality and Social Psychology Bulletin, 37, 492-501.

Pellegrini, E. K., \& Scandura, T. A. (2008). Paternalistic leadership: A review and agenda for future research. Journal of Management 34, 566-593.

Pronin, E., \& Ross, L. (2006). Temporal differences in trait self ascription: When the self is seen as another. Journal of Personality and Social Psychology, 90, 197-209.

Rinne, T., Steel, G. D., \& Fairweather, J. (2012) Hofstede and Shane revisited the role of power distance and individualism in national-level innovation success. CrossCultural Research, 46, 91-108.

Rinne, T., Steel, G. D., \& Fairweather, J. (2013). The role of Hofstede's individualism in national-level creativity. Creativity Research Journal, 25, 129-136.

Roberts, D. (2014, May). China exam system drives student suicides. Bloomberg. Retrieved from http://www.bloomberg.com/news/articles/2014-05-15/china-examsystem-drives-student-suicides.

Roe, A. (1952). The making of a scientist. New York, NY: Dodd, Mead.

Russ, S. W. (1993). Affect and creativity: The role of affect and play in the creative process. Hillsdale, NJ: Erlbaum \& Associates.

Schneider, B., \& Lee, Y. (1990). A model for academic success: The school and home environment of East Asian students. Anthropology \& Education Quarterly, 21, 358-377.

Schroth, R. A. (2012, May). The plagiarism plague. America: The national catholic weekly. Retrieved from http://www.americamagazine.org/content/article.cfm? article_id=13413

Steinberg, L., Dornbusch, S., \& Brown, B. B. (1992). Ethnic differences in adolescent achievement: An ecological perspective. American Psychologist, 47, 723-729.

Sternberg, R. J., \& Kaufman, J. C. (2010). Constraints on creativity. In J. C. Kaufman \& R. J. Sternberg (Eds.), The Cambridge handbook of creativity (pp. 467-482). New York, NY: Cambridge University Press.

Suen, H. K., \& Yu, L. (2006). Chronic consequences of high-stakes testing? Lessons from the Chinese civil service exam. Comparative Education Review, 50(1), 46-65.

Tan, P., Morgan, S., \& Zagheni, E. (2016). A case for "reversed one-child" policies in Japan and South Korea? Examining the link between education costs and lowest-low fertility. Population Research and Policy Review, 35, 327-350. 
Taylor, M. Z., \& Wilson, S. (2012). Does culture still matter? The effects of individualism on national innovation rates. Journal of Business Venturing, 27, 234-247.

Tellis, G. J., Prabhu, J. C., \& Chandy, R. K. (2009). Radical innovation across nations: The preeminence of corporate culture. Journal of Marketing, 73(1), 3-23.

Terman, L. M. (1954). The discovery and encouragement of exceptional talent. American Psychologist, 9, 221-230.

Thrash, T. M., Maruskin, L. A., Cassidy, S. E., Fryer, J. W., \& Ryan, R. M. (2010). Mediating between the muse and the masses: Inspiration and the actualization of creative ideas. Journal of Personality and Social Psychology, 98, 469-487.

Torrance, E. P., \& Safter, H. T. (1999). Making the creative leap beyond. Buffalo, NY: Creative Education Foundation Press.

Vagle, M. D. (2014). Crafting phenomenological research. Walnut Creek, CA: Left Coast Press.

Varsakelis, N. C. (2001). The impact of patent protection, economy openness and national culture on R\&D investment: A cross-country empirical investigation. Research Policy, 30, 1059-1068.

Valdez, C., Shewakramani, V., Goldberg, S., \& Padilla, B. (2013). Parenting influences on Latino children's social competence in the first grade: Parental depression and parent involvement at home and school. Child Psychiatry \& Human Development, $44,646-657$.

Wakslak, C. J., Trope, Y., Liberman, N., \& Alony, R. (2006). Seeing the forest when entry is unlikely: Probability and the mental representation of events. Journal of Experimental Psychology: General, 135, 641-653.

Walsh, C. (2013). Jobs, Einstein, and Franklin: Isaacson deconstructs their genius and dedication to larger goals. Harvard Gazette. Retrieved from http:// news.harvard.edu/gazette/ stroy/2013/04/jobs-einstein-and-franklin/

Wang, L. C. (2015). The effect of high-stakes testing on suicidal ideation of teenagers with reference-dependent preferences. Journal of Population Economics, 29, 345-364.

Williams, P., Barclay, L., \& Schmied, V. (2004). Defining social support in context: A necessary step in improving research, intervention, and practice. Qualitative Health Research, 14, 942-960.

Weisberg, P.S., \& Springer, K. J. (1961). Environmental factors in creative functions: A study of gifted children. Archives of General Psychiatry, 5, 64-74. 
Xu, M., Benson, S. N. K., Mudrey-Camino, R., \& Steiner, R. P. (2010). The relationship between parental involvement, self-regulated learning, and reading achievement of fifth graders: A path analysis using the ECLS-K database. Social Psychology of Education, 13, 237-269.

Yan, M-C., Kim, S., Kang, H-J., \& Wilkerson, K. L. (2017). Perceptions of disability and special education among East Asian parents. Journal of International Special Needs Education, 20(1), 41-55.

Yang, S., \& Shin, C. S. (2008). Parental attitudes towards education: What matters for children's well-being? Children and Youth Services Review, 30, 1328-1335.

Yonngong (2015). Suicide No. 1 cause of death for S. Korean teens, youths. Yonhap News Agency. Retrieved from http://english.yonhapnews.co.kr/ national/2015/04/28/11/0302000000AEN20150428004700320F.html

Corresponding author at: Kyung Hee Kim, 301 Monticello Avenue, PO Box 8795, William \& Mary, Williamsburg, VA 23187, USA.

E-mail: kkim@wm.edu 